\title{
Penambahan Filtrat Tepung Umbi Dahlia (Dahlia variabilis Willd.) sebagai Prebiotik dalam Pembuatan Yoghurt Sinbiotik
}

\author{
Khabib Khasan Al Faridhi ${ }^{1}$, Arina Tri Lunggani ${ }^{1}$ dan Endang Kusdiyantini ${ }^{1}$ \\ 1. Jurusan Biologi, Fakultas Sains dan Matematika, Universitas Diponegoro, Tembalang, Semarang 50275 \\ Telepon (024) 7474754; Fax. (024) 76480690 \\ email: khabib.khasan@yahoo.com
}

\begin{abstract}
Abstrak
Yoghurt is a fermented milk product that can provide beneficial effects to the health of consumers. Increasing the quality of yoghurt can be made by combining the benefits of probiotic with prebiotic to produce sinbiotic yoghurt. Inulin is a prebiotic that found in many dahlia tuber (Dahlia variabilis Willd.). Pure inulin were expensive, so the alternative is using dahlia tuber flours filtrate as prebiotic ingredients. This study aimed to examine the addition of Dahlia Tuber Flours Filtrate (DTFF) as a prebiotic in sinbiotic yoghurt making using Lactic Acid Bacteria (LAB) Lactobacillus bulgaricus, Streptococcus termophilus dan Lactobacillus acidopilus as probiotic. This research using Completely Randomized Design (CRD) with 4 concentration treatments DTFF 0\%, 3\%, 6\% and 9\% with 3 replications. Observed variables consist of the number of total LAB, lactic acid level, $\mathrm{pH}$ and organoleptic attributes (aroma, flavor, consistency and impression). Data the number of total LAB, lactic acid level and $\mathrm{pH}$ values were analyzed by ANOVA, continued by Duncan test, while the organoleptic data was analyzed by Mann-Whitney $\mathrm{U}$ test with $95 \%$ significant level. The results showed that the addition of DTFF significantly affect the increasing of total LAB, lactic acid level, organoleptic assessment and decreasing $\mathrm{pH}$ of sinbiotic yoghurt. Sinbiotic yoghurt with $3 \%$ of DTFF concentration is most preferred by panelists and required the criteria of Indonesian National Standard (SNI) for yoghurt with enough likely aroma, sour taste/specify and enough thick texture with total LAB $2,4 \times 10^{8}$ $\mathrm{CFU} / \mathrm{ml}, 1.3 \%$ lactic acid levels and 4.2. $\mathrm{pH}$.
\end{abstract}

Keywords : prebiotic, probiotic, inulin, dahlia tuber, sinbiotic yoghurt, lactobacillus bulgaricus, streptococcus termophilus, lactobacillus acidopilus

\begin{abstract}
Abstrak
Yoghurt merupakan produk susu fermentasi yang mampu memberikan efek menguntungkan bagi kesehatan konsumen. Peningkatan kualitas yoghurt dapat dilakukan dengan menggabungkan manfaat antara probiotik dengan prebiotik untuk menghasilkan yoghurt sinbiotik. Inulin merupakan prebiotik yang banyak terdapat pada umbi tanaman dahlia (Dahlia variabilis Willd.). Inulin murni harganya cukup mahal, sehingga alternatif yang dapat dilakukan yaitu dengan memanfaatkan filtrat tepung umbi dahlia sebagai bahan prebiotik. Penelitian ini bertujuan untuk mengkaji penambahan Filtrat Tepung Umbi Dahlia (FTUD) sebagai prebiotik dalam pembuatan yoghurt sinbiotik dengan menggunakan Bakteri Asam Laktat (BAL) Lactobacillus bulgaricus, Streptococcus termophilus dan Lactobacillus acidopilus sebagai probiotik. Penelitian ini menggunakan Rancangan Acak Lengkap (RAL) dengan 4 perlakuan konsentrasi FTUD 0\%, 3\%, 6\% dan 9\% dengan 3 ulangan. Variabel yang diamati meliputi jumlah total BAL, kadar asam laktat, nilai $\mathrm{pH}$, dan atribut organoleptik (aroma, rasa, kekentalan dan kesan). Data jumlah total BAL, kadar asam laktat dan nilai pH dianalisis dengan ANOVA dan dilanjutkan dengan uji Duncan, sedangkan data organoleptik dianalisis dengan uji Mann-Whitney U dengan taraf kepercayaan 95\%. Hasil penelitian menunjukkan bahwa penambahan FTUD berpengaruh nyata terhadap peningkatan jumlah total BAL, kadar asam laktat, penilaian organoleptik dan penurunan $\mathrm{pH}$ yoghurt sinbiotik. Yoghurt sinbiotik dengan konsentrasi FTUD 3\% paling disukai oleh panelis dan sudah memenuhi kriteria Standar Nasional Indonesia (SNI) untuk yoghurt dengan aroma yang cukup disukai, rasa asam/khas dan tekstur yang cukup kental dengan jumlah total BAL 2,4 x $10^{8}$ $\mathrm{CFU} / \mathrm{ml}$, kadar asam laktat $1,3 \%$ dan $\mathrm{pH} 4,2$.
\end{abstract}

Kata kunci : prebiotik, probiotik, inulin, umbi dahlia, yoghurt sinbiotik, lactobacillus bulgaricus, streptococcus termophilus, lactobacillus acidopilus 


\section{PENDAHULUAN}

Yoghurt merupakan produk fermentasi susu dengan menggunakan Streptococcus thermophilus dan Lactobacillus bulgaricus sebagai bakteri starternya (Indratininingsih dkk., 2004). Yoghurt mempunyai nilai gizi yang lebih tinggi daripada susu segar sebagai bahan dasar dalam pembuatan yoghurt, terutama karena meningkatnya total padatan, sehingga kandungan zat-zat gizi lainnya juga meningkat. Selain itu, yoghurt sesuai bagi penderita lactose intolerance atau yang tidak toleran terhadap laktosa (Wahyudi, 2006).

Konsumsi yoghurt dari tahun ke tahun semakin meningkat hal ini dapat dilihat dari nilai perkembangan akan yoghurt, pada tahun 20022005 volume yoghurt mengalami peningkatan dari 1.039.279 liter, 1.536.824 liter, 1.682.612 liter, dan 1.765.831 liter (Badan Pusat Statistik, 2011 dalam Suganda, 2012). Meningkatnya konsumsi dan permintaan akan yoghurt ini diantaranya karena yoghurt memiliki citarasa yang khas, asam, segar dan memiliki banyak manfaat bagi kesehatan tubuh (Suganda, 2012). Oleh karena itu, peningkatan konsumsi dan permintaan akan yoghurt ini sebaiknya dibarengi dengan peningkatan kualitas yoghurt. Peningkatan kualitas yoghurt dapat dilakukan dengan mengkombinasikan manfaat antara kultur starter dari bakteri probiotik dengan substrat pertumbuhan bakteri probiotik yaitu prebiotik. Penggabungan antara probiotik dengan prebiotik disebut sinbiotik (Gibson \& Roberfroid, 2008 dalam Zain, 2010). Produk sinbiotik diharapkan dapat meningkatkan daya hidup bakteri dan menyimpan makanan bagi mikroba dalam saluran pencernaan yang dapat meningkatkan kesehatan inangnya.

Salah satu prebiotik yang dapat dimanfaatkan adalah inulin. Inulin merupakan polisakarida (khususnya fruktan) yang terdiri atas unit-unit fruktosa dengan ikatan glikosidik $\beta$-(2-1) dan terminal glukosa pada ujungnya (Zain, 2010). Inulin bersifat larut di dalam air, tidak dapat dicerna oleh enzim-enzim pencernaan, tetapi difermentasi mikroflora kolon (usus besar). Oleh karena itu, inulin berfungsi sebagai prebiotik (Widowati, 2006). Sumber inulin yang banyak terdapat di Indonesia adalah dari umbi tanaman dahlia (Dahlia variabilis Willd.). Rahayuningsih
\& Purnawati (1993 dalam Widowati dkk., 2005) menyatakan, sumber inulin yang terdapat di Indonesia adalah umbi tanaman dahlia yang dikenal sebagai tanaman hias yang dimanfaatkan bunganya. Kandungan inulin dalam umbi dahlia sekitar 60\%.

Inulin dari umbi dahlia dapat diperoleh dalam bentuk inulin murni (komersial) atau dari umbi dahlianya tersebut. Inulin murni (komersial) harganya cukup mahal. Saputri (2012) menyatakan bahwa industri pangan, kimia dan farmasi Indonesia masih melakukan impor inulin dan FOS dari Eropa dan Amerika Serikat hingga 100 persen. Padahal, inulin yang dihasilkan umbi dahlia kualitasnya lebih baik dari yang tersedia di pasaran dunia sekarang. Hal ini dikarenakan inulin dari umbi dahlia saat ini masih dibanderol harga tinggi, yakni Rp 7 juta per kilogram. Harga ini sangat tinggi dibandingkan dengan harga inulin yang dijual di pasaran, yang hanya Rp 1 juta per $5 \mathrm{~kg}$. Inulin murni (komersial) harganya cukup mahal, sehingga alternatif yang dapat dilakukan yaitu dengan memanfaatkan umbi dahlia menjadi tepung umbi dahlia yang diambil filtratnya sebagai sumber inulin. Sehubungan dengan hal tersebut, maka diperlukan penelitian untuk mengkaji penambahan filtrat tepung umbi dahlia (Dahlia variabilis Willd.)sebagai prebiotik dalam pembuatan yoghurt sinbiotik.

\section{BAHAN DAN METODE Bahan}

Bahan-bahan yang digunakan dalam penelitian ini meliputi umbi dahlia yang diperoleh dari daerah Bandungan, Semarang pada bulan Agustus 2010, susu skim, starter yoghurt komersial yang berisi kultur campuran bakteri Lactobacillus bulgaricus, Streptococcus termophillus dan Lactobacillus acidopilus yang diperoleh dari CV. Microlab Bandung, akuades, agar, MRS (deMann Rogosa Sharpe, Oxoid), larutan phenolphtalein $1 \%$, alkohol $70 \%, \mathrm{NaOH}$ $0,1 \mathrm{~N}$, kertas saring dan buffer $\mathrm{pH} 4$ dan 7 .

\section{Pembuatan Tepung Umbi Dahlia}

Umbi dahlia yang sudah dicuci bersih dikupas, dipotong kecil-kecil dan dikeringkan dalam oven pada suhu $80^{\circ} \mathrm{C}$. Umbi dahlia yang 
sudah kering selanjutnya digiling sampai menjadi tepung (Wijanarka dkk., 2004).

\section{Pembuatan Starter Yoghurt}

Susu skim sebanyak $13 \mathrm{~g}$ dilarutkan dalam akuades $100 \mathrm{ml}$. Susu skim cair selanjutnya dipasteurisasi pada suhu $80^{\circ} \mathrm{C}$ selama 15 menit. Susu skim yang sudah dipasteurisasi kemudian didinginkan hingga suhu $42^{\circ} \mathrm{C}$. Starter yoghurt komersial sebanyak 4\% (b/v) diinokulasikan ke dalam susu skim dan dicampur hingga rata, kemudian diinkubasi pada suhu $42^{\circ} \mathrm{C}$ selama 6 jam.

\section{Pembuatan Yoghurt Sinbiotik}

Tepung umbi dahlia sesuai perlakuan yaitu : $\mathrm{P}_{0}=0 \%, \mathrm{P}_{1}=3 \%, \mathrm{P}_{2}=6 \%$, dan $\mathrm{P}_{3}=9 \%$ dilarutkan dalam 50ml akuades, kemudian dipanaskan sampai $80-90^{\circ} \mathrm{C}$ selama \pm 30 menit. Setelah dingin, disaring untuk diambil filtratnya dan disterilisasi pada suhu $121^{\circ} \mathrm{C} 2 \mathrm{~atm}$ selama 15 menit (Modifikasi metode Yuliana, 2009). Susu skim sebanyak $13 \mathrm{~g}$ dilarutkan dalam $50 \mathrm{ml}$ akuades kemudian dipasteurisasi pada suhu $80^{\circ} \mathrm{C}$ selama 15 menit. Susu skim yang telah dipasteurisasi dan filtrat tepung umbi dahlia yang telah disterilisasi kemudian di campur menjadi satu, sehingga total larutan menjadi $100 \mathrm{ml}$. Medium campuran susu skim dan filtrat tepung umbi dahlia kemudian didinginkan hingga suhu $42^{\circ} \mathrm{C}$ dan diinokulasi dengan starter yoghurt sebanyak 3\% (v/v). Masing-masing perlakuan kemudian diinkubasi pada suhu $42^{\circ} \mathrm{C}$ selama 6 jam. Masing-masing perlakuan diulang 3 kali.

\section{Pengukuran Kadar Asam Laktat}

Pengukuran kadar asam laktat yoghurt dilakukan sebagai berikut: $10 \mathrm{~g}$ sampel diletakkan di dalam erlenmeyer dan ditambah dengan 2-3 tetes larutan phenolphtalein $1 \%$ sebagai indikator. Kemudian dititrasi dengan larutan $\mathrm{NaOH} 0,1 \mathrm{~N}$ hingga warnanya berubah menjadi kemerahmerahan, volume $\mathrm{NaOH}$ yang digunakan untuk titrasi dicatat. Kadar asam laktatnya dihitung dengan menggunakan rumus sebagai berikut :

Kadar Asam Laktat $(\%)=$

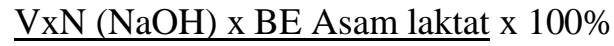
Berat sampel (gram)
Keterangan :

$\mathrm{V}$ = volume $\mathrm{NaOH}$ yang digunakan untuk titrasi (ml)

$\mathrm{N}=$ Normalitas $\mathrm{NaOH}(0,1 \mathrm{~N})$

$\mathrm{BE}=$ Berat ekuivalen asam laktat (90/1000) (Hadiwiyoto, 1994).

\section{Penghitungan Jumlah Total BAL}

Sampel yoghurt sebanyak $1 \mathrm{ml}$ dimasukkan ke dalam tabung berisi $9 \mathrm{ml}$ aquades steril (pengenceran $10^{-1}$ ). Pengenceran dilakukan secara berseri $\left(10^{-1}, 10^{-2}, 10^{-3}\right.$ dan seterusnya) sampai diperoleh tingkat pengenceran yang dikehendaki. Selanjutnya sebanyak $1 \mathrm{ml}$ dari tingkat pengenceran yang dikehendaki, dipipet ke dalam cawan petri steril kemudian ditambah kurang lebih $10 \mathrm{ml}$ media MRS agar. Selanjutnya diinkubasi selama 48 jam pada suhu $37^{\circ} \mathrm{C}$ dan dihitung koloni yang tumbuh (Fardiaz., 1993).

\section{Pengukuran Nilai pH}

Pengukuran $\mathrm{pH}$ yoghurt dilakukan dengan menggunakan $\mathrm{pH}$ meter dengan cara mencelupkan ujung katoda $\mathrm{pH}$ meter ke dalam sample yoghurt. Sebelum dan sesudah pencelupan katoda ke dalam sample, terlebih dahulu $\mathrm{pH}$ meter dikalibrasi dengan larutan buffer pH 7 (Hadiwiyoto, 1994).

\section{Uji Organoleptik}

Penilaian dilakukan terhadap rasa, aroma, kekentalan dan kesan terhadap produk. Skala nilai terhadap rasa dimulai dari 1 (tawar), 2 (agak asam), 3 (asam/khas), 4 (sangat asam). Skala nilai terhadap aroma dimulai dari 1 (tidak suka), 2 (agak tidak suka), 3 (netral), 4 (cukup suka), 5 (suka), 6 (sangat suka). Skala nilai terhadap kekentalan dimulai dari 1 (encer), 2 (sedang), 3 (kental). Skala nilai terhadap kesan dimulai dari 1 (tidak suka), 2 (agak tidak suka), 3 (netral), 4 (cukup suka), 5 (suka), 6 (sangat suka). Penilaian dilakukan oleh 25 orang panelis. Nilai yang dilaporkan adalah nilai rataan dari jumlah panelis tersebut (Soekarto, 1985).

\section{Variabel Penelitian}

Variabel yang diamati meliputi jumlah total bakteri asam laktat, kadar asam laktat, nilai $\mathrm{pH}$, dan sifat organoleptik (aroma, rasa, kekentalan dan kesan). 


\section{Rancangan Percobaan dan Analisis Data}

Penelitian ini menggunakan Rancangan Acak Lengkap (RAL) dengan 4 perlakuan konsentrasi FTUD 0\%, 3\%, 6\% dan 9\% dengan 3 ulangan. Data jumlah total BAL, kadar asam laktat dan nilai $\mathrm{pH}$ dianalisis dengan ANOVA dan dilanjutkan dengan uji Duncan, sedangkan data organoleptik dianalisis dengan uji Mann-Whitney $\mathrm{U}$ dengan taraf kepercayaan $95 \%$.

\section{HASIL DAN PEMBAHASAN}

Jumlah Total BAL Yoghurt Sinbiotik

Penambahan FTUD dengan konsentrasi yang berbeda-beda ke dalam yoghurt menyebabkan terjadinya peningkatan jumlah total BAL (Gambar 1.).

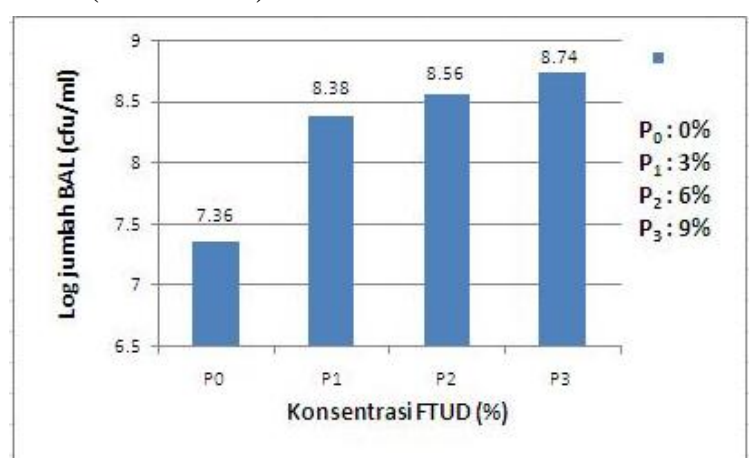

Gambar 1. Log jumlah BAL yoghurt sinbiotik dengan penambahan konsentrasi FTUD yang berbeda

Bakteri asam laktat diduga memanfaatkan laktosa dan inulin yang terdapat pada yoghurt sinbiotik sebagai sumber energi untuk pertumbuhannya yang akhirnya akan menghasilkan asam laktat. James \& Sareen (2000 dalam Rosa, 2010) menyatakan bahwa inulin akan difermentasi oleh bakteri asam laktat dengan menghasilkan asam laktat serta asam-asam lemak rantai pendek (asetat, butirat, propionate). Laktosa dalam yoghurt juga akan diubah menjadi galaktosa dan glukosa oleh enzim laktase atau phosphogalaktosidase. Glukosa yang terbentuk, selanjutnya akan dimetabolisme oleh bakteri asam laktat menjadi asam laktat (Tamime \& Deeth, 1989 dalam Purwijantiningsih, 2007).

Berdasarkan hasil analisis varian, perbedaan konsentrasi FTUD sebagai sumber prebiotik (inulin) berpengaruh tidak nyata terhadap total BAL yoghurt sinbiotik pada perlakuan $\mathrm{P}_{1}, \mathrm{P}_{2}$ dan $\mathrm{P}_{3}$ dan berpengaruh nyata pada perlakuan $\mathrm{P}_{0}$. Total BAL yoghurt sinbiotik yang dihasilkan berkisar antara $2,3 \times 10^{7}-5,5 \times 10^{8} \mathrm{CFU} / \mathrm{ml}$. Peningkatan konsentrasi FTUD yang ditambahkan pada yoghurt menyebabkan semakin meningkatnya jumlah total BAL yang dihasilkan dalam yoghurt sinbiotik ini.

Jumlah bakteri starter yang terkandung pada yoghurt menurut Badan Standardisasi Nasional (SNI) 2981:2009 harus mencapai minimal $10^{7}$ koloni/gram. Penelitian ini menggunakan starter yoghurt dengan jumlah total BAL starter $1,2 \times 10^{7} \mathrm{CFU} / \mathrm{ml}$ dan yoghurt sinbiotik yang dihasilkan mempunyai jumlah total BAL berkisar 2,3 x 107-5,5 x $10^{8} \mathrm{CFU} / \mathrm{ml}$, dengan demikian jumlah total BAL yoghurt sinbiotik yang dihasilkan bisa dikatakan sudah memenuhi kriteria SNI yoghurt.

\section{Kadar Asam Laktat Yoghurt Sinbiotik}

Penambahan FTUD dengan konsentrasi yang berbeda-beda ke dalam yoghurt menyebabkan terjadinya peningkatan kadar asam laktat (Gambar 2.).

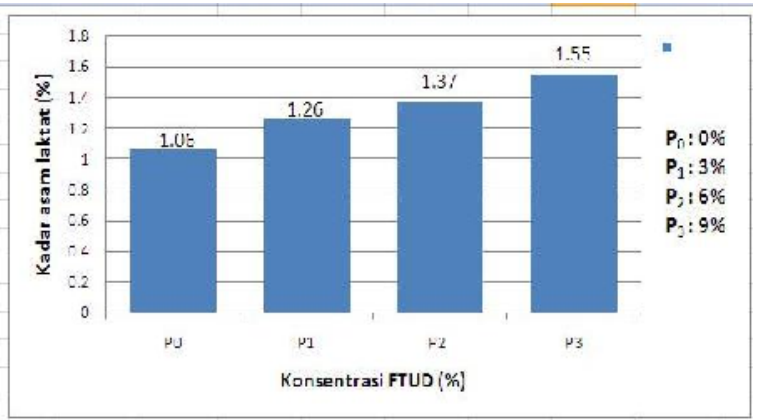

Gambar 2. Kadar asam laktat yoghurt sinbiotik dengan penambahan konsentrasi FTUD yang berbeda

Peningkatan kadar asam laktat yoghurt sinbiotik terjadi seiring dengan peningkatan konsentrasi FTUD sebagai prebiotik. Bakteri asam laktat diduga memanfaatkan laktosa dan inulin yang terdapat pada yoghurt sinbiotik sebagai sumber energy selama fermentasi susu menjadi yoghurt, sehingga terjadi akumulasi kadar asam laktat pada yoghurt sinbiotik yang dihasilkan.. Hal 
ini sesuai dengan pendapat Tamime \& Deeth (1989 dalam Purwijantiningsih, 2007) yang menyatakan bahwa bakteri asam laktat akan mengubah laktosa dalam susu menjadi asam laktat selama berlangsungnya fermentasi susu menjadi yoghurt. Laktosa dalam susu ditransfer ke dalam sel oleh enzim permease, kemudian oleh enzim laktase atau phospho-galaktosidase diubah menjadi galaktosa dan glukosa. Glukosa yang terbentuk, selanjutnya oleh bakteri asam laktat dimetabolisme menjadi asam laktat. James \& Sareen (2000 dalam Rosa, 2010) juga menyatakan bahwa inulin akan difermentasi oleh bakteri asam laktat dengan menghasilkan asam laktat serta asam-asam lemak rantai pendek (asetat, butirat, propionate).

Hasil analisis varian menunjukkan bahwa perbedaan konsentrasi FTUD sebagai sumber prebiotik (inulin) berpengaruh nyata terhadap kadar asam laktat yoghurt sinbiotik. Semakin banyak konsentrasi FTUD yang ditambahkan, maka total asam laktat tertitrasi pun akan semakin meningkat. Rata-rata kadar asam laktat yang terbentuk pada yoghurt sinbiotik ini berkisar antara $1,1-1,6 \%$. Kandungan asam laktat yoghurt yang disyaratkan menurut SNI berkisar antara 0,5-2,0\% (Badan Standardisasi Nasional, 2009), dengan demikian kadar asam laktat yoghurt sinbiotik yang dihasilkan bisa dikatakan sudah memenuhi kriteria SNI yoghurt.

\section{Nilai pH Yoghurt Sinbiotik}

Penambahan FTUD dengan konsentrasi yang berbeda-beda ke dalam yoghurt menyebabkan terjadinya penuruhan $\mathrm{pH}$ yoghurt (Gambar 3.).

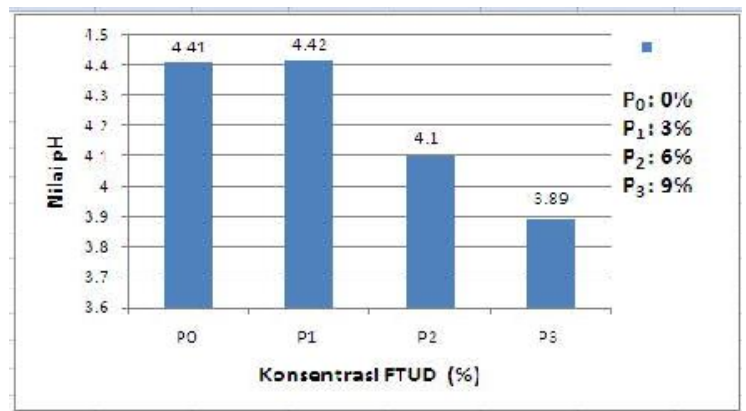

Gambar 3. Nilai pH yoghurt sinbiotik dengan penambahan konsentrasi FTUD yang berbeda
Hasil analisis varian penambahan konsentrasi FTUD yang berbeda berpengaruh nyata terhadap penuruhan $\mathrm{pH}$ yoghurt. Rata-rata nilai $\mathrm{pH}$ yoghurt sinbiotik menurun seiring dengan penambahan konsentrasi FTUD pada masingmasing perlakuan. FTUD sebagai sumber prebiotik yang mengandung inulin berperan dalam meningkatkan aktivitas dan pertumbuhan BAL, sehingga mempercepat penurunan $\mathrm{pH}$. Semakin besar penambahan konsentrasi FTUD, maka semakin besar pula kandungan inulin yang terdapat di dalam yoghurt, sehingga $\mathrm{pH}$ yoghurt semakin menurun seiring bertambahnya produksi asam laktat. James \& Sareen (2000 dalam Rosa, 2010) menyatakan inulin akan difermentasi oleh bakteri asam laktat dengan menghasilkan asam laktat serta asam-asam lemak rantai pendek (asetat, butirat, propionate). Produk dari bakteri tersebut akan menurunkan $\mathrm{pH}$ yoghurt.

Penurunan nilai $\mathrm{pH}$ yoghurt sinbiotik ini disebabkan oleh hasil penguraian gula-gula sederhana dari inulin dan laktosa menjadi asam laktat selama proses fermentasi. Nilai $\mathrm{pH}$ berbanding terbalik dengan kadar asam laktat. Semakin banyak kadar asam laktat yang dihasilkan, maka nilai $\mathrm{pH}$ akan semakin rendah. Semakin banyak konsentrasi inulin yang terkandung dalam FTUD yang ditambahkan pada yoghurt, maka semakin meningkat jumlah total BALnya dan semakin banyak asam laktat yang dihasilkan, sehingga pH akan semakin cepat menurun. Hal ini sesuai dengan pendapat Purwijantiningsih (2007), yang menyatakan bahwa dihasilkannya asam laktat sebagai hasil metabolisme gula menyebabkan penurunan $\mathrm{pH}$ yoghurt. Hal tersebut berkaitan dengan semakin meningkatnya jumlah bakteri asam laktat yang akan menggunakan laktosa untuk diubah menjadi asam laktat yang menyebabkan penurunan $\mathrm{pH}$.

Menurut Rahayu (1987), nilai $\mathrm{pH}$ yang baik untuk yoghurt adalah antara 4,2-4,5 karena pada $\mathrm{pH}$ tersebut protein pada susu akan menggumpal dan membentuk gel yoghurt. Rata-rata nilai $\mathrm{pH}$ yoghurt sinbiotik dari hasil penelitian ini berkisar antara 3,9-4,4 dengan demikian bisa dikatakan yoghurt sinbiotik yang dihasilkan sudah memenuhi standar $\mathrm{pH}$ yoghurt yang baik. 


\section{Uji Organoleptik}

Uji organoleptik digunakan untuk mengetahui tingkat penerimaan konsumen terhadap minuman yoghurt sinbiotik yang dihasilkan.

\section{Aroma yoghurt sinbiotik}

Hasil analisis menggunakan uji MannWhitney U menunjukkan bahwa, penambahan FTUD dengan konsenrtasi yang berbeda memberikan pengaruh yang berbeda tidak nyata terhadap nilai aroma yoghurt sinbiotik. Nilai aroma yoghurt sinbiotik yang dihasilkan berkisar antara 3,92-4,44 (Gambar 4.) yang menunjukkan panelis cenderung merasakan netral sampai cukup suka.

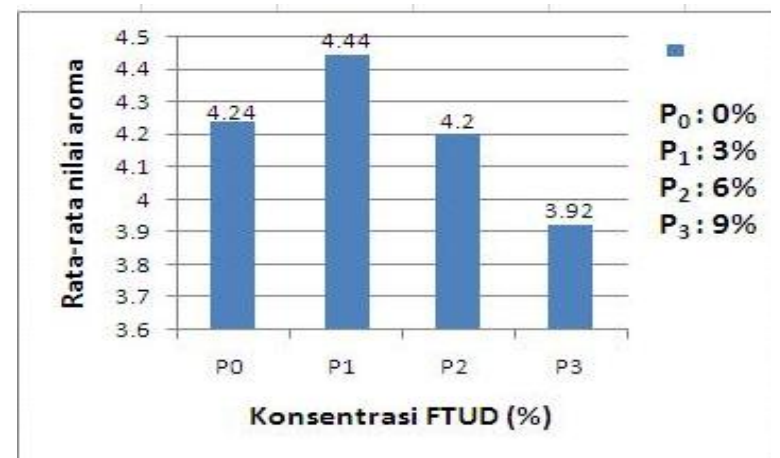

Gambar 4. Rata-rata nilai aroma yoghurt sinbiotik dengan penambahan konsentrasi FTUD yang berbeda

Kesukaan panelis terhadap aroma yoghurt sinbiotik ini mungkin juga dipengaruhi oleh aroma khas dari tepung umbi dahlia, karena aroma tepung umbi dahlia masih sedikit terasa pada yoghurt sinbiotik yang dihasilkan. Menurut Rachman (1989), aroma yoghurt ditentukan oleh terbentuknya asam laktat, asetaldehida, asam asetat dan asetil. Aroma yoghurt pada dasarnya disebabkan oleh terbentuknya asam laktat dan senyawa karbonil seperti asetaldehida. Tamime \& Robinson (1991) dalam Susanti, 2005) juga mengatakan asetaldehida dan beberapa komponen yang tidak teridentifikasi sebagai senyawa yang menyebabkan timbulnya aroma khas yoghurt.

\section{Rasa yoghurt sinbiotik}

Hasil analisis menggunakan uji MannWhitney U menunjukkan bahwa penambahan konsentrasi FTUD yang berbeda berpengaruh secara nyata terhadap nilai rasa yoghurt sinbiotik. Nilai rasa yoghurt sinbiotik yang dihasilkan berkisar antara 2,92-3,52 (Gambar 5.) yang menunjukkan panelis cenderung merasakan agak asam sampai asam khas.

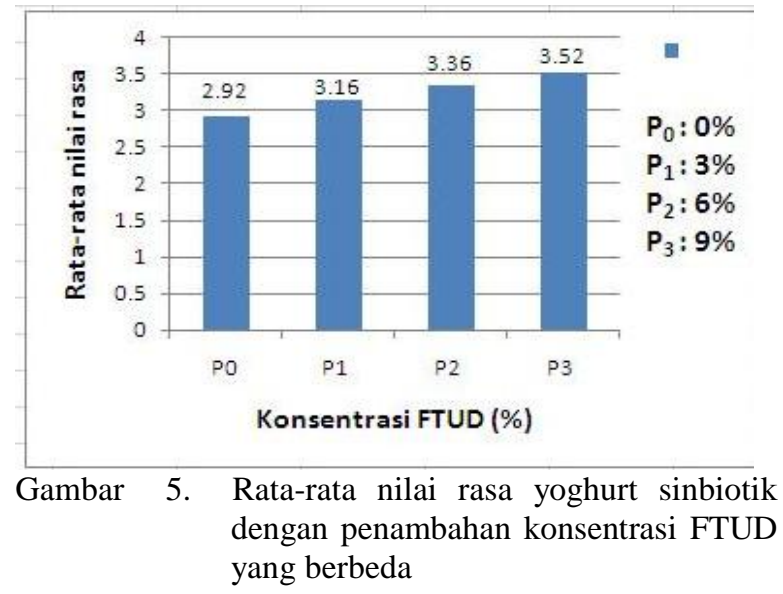

Rasa asam merupakan salah satu rasa yang menjadi ciri khas yoghurt, karena terbentuknya asam laktat dan asetaldehida. Menurut Chandan \& Shahani (1993 dalam Yusmarini \& Efendi, 2004), hasil metabolisme karbohidrat (gula) berupa asamasam organik seperti asam laktat akan mempengaruhi citarasa dan ikut menentukan kualitas yoghurt. Semakin banyak kandungan inulin dalam FTUD yang ditambahkan, maka jumlah total BAL pun akan semakin meningkat, karena memanfaatkan inulin dan laktosa yang ada sebagai sumber energi dan pertumbuhan BAL tersebut. Peningkatan jumlah total BAL akan berpengaruh pada peningkatan produksi asam laktat dan penurunan $\mathrm{pH}$ yoghurt menjadi semakin asam.

\section{Kekentalan yoghurt sinbiotik}

Hasil analisis menggunakan uji MannWhitney U menunjukkan bahwa, penambahan FTUD dengan konsentrasi yang berbeda memberikan pengaruh yang berbeda nyata terhadap nilai kekentalan yoghurt sinbiotik. Nilai kekentalan yoghurt sinbiotik yang dihasilkan berkisar antara 2,64-2,92 (sedang) (Gambar 4.6.).

Salah satu karakteristik yoghurt adalah teksturnya yang kental. Tekstur dan rasa yoghurt 
dipengaruhi oleh konsentrasi prebiotik (FTUD). Semakin tinggi penambahan konsentrasi FTUD, maka yoghurt yang dihasilkan akan semakin kental. Hal ini disebabkan adanya $\mathrm{pH}$ isoelektrik dan proses gelatinisasi. FTUD mengandung inulin sebagai sumber nutrisi bakteri probiotik yang akan difermentasi, sehingga menyebabkan $\mathrm{pH}$ yoghurt menjadi turun. Kelarutan protein akan menurun pada saat $\mathrm{pH}$ mencapai $4-4.5$ ( $\mathrm{pH}$ isoelektrik), kemudian protein akan menggumpal (Simanjuntak, 2003 dalam Rosa, 2010).

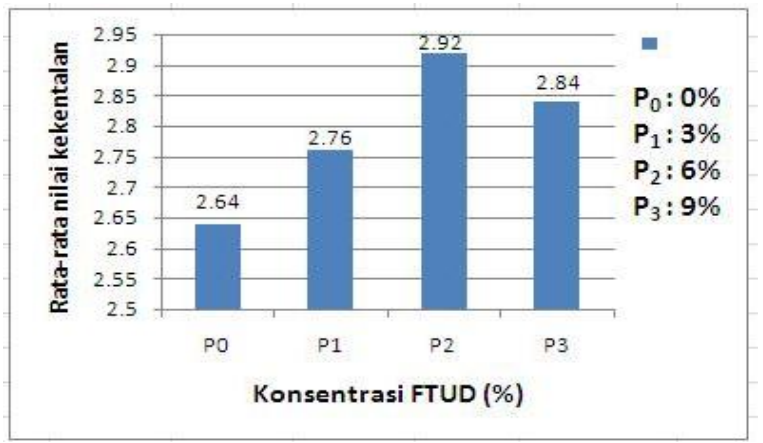

Gambar 6. Rata-rata nilai kekentalan yoghurt sinbiotik dengan penambahan konsentrasi FTUD yang berbeda

\section{Kesan yoghurt sinbiotik}

Penilaian kesan panelis dilakukan untuk mengetahui tingkat penerimaan konsumen terhadap yoghurt sinbiotik, meliputi penilaian terhadap aroma, citarasa, dan kekentalan yoghurt yang sudah dilakukan sebelumnya. Hasil analisis menggunakan uji Mann-Whitney U menunjukkan bahwa, penambahan FTUD dengan konsentrasi yang berbeda memberikan pengaruh yang berbeda nyata terhadap nilai kesan yoghurt sinbiotik. Nilai kesan yoghurt sinbiotik yang dihasilkan berkisar antara 3,92-4,48 (Gambar 7.) yang menunjukkan panelis cenderung merasakan netral sampai cukup suka.

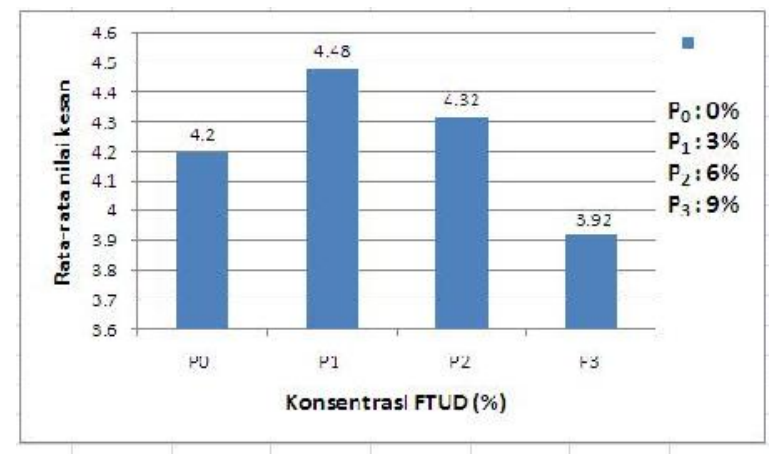

Gambar 7. Rata-rata nilai kesan yoghurt sinbiotik dengan penambahan konsentrasi FTUD yang berbeda

Perbedaan kesan atau tingkat kesukaan terhadap yoghurt sinbiotik ini berkaitan erat dengan citarasa yoghurt. Kebanyakan panelis lebih menyukai yoghurt sinbiotik yang rasanya asam/khas. Hartati et al. (2003 dalam Nurwantoro dkk., 2009) menyatakan bahwa tingkat penerimaan panelis secara keseluruhan pada produk fermentasi dengan starter BAL sangat dipengaruhi oleh tingkat keasaman produk, dimana tingkat keasaman yang semakin meningkat akan semakin menurunkan tingkat penerimaan panelis.

Berdasarkan data yang diperoleh, penilaian tertinggi terhadap aroma diperoleh oleh $\mathrm{P}_{1}$ yaitu 4,44 (cukup suka), penilaian tertinggi terhadap rasa diperoleh oleh $\mathrm{P}_{3}$ yaitu 3,52 (asam/khas), penilaian tertinggi terhadap kekentalan diperoleh oleh $\mathrm{P}_{2}$ yaitu 2,92 (sedang), dan penilaian tertinggi terhadap kesan diperoleh oleh $\mathrm{P}_{1}$ yaitu 4,48 (cukup suka). Berdasarkan rata-rata penilaian organoleptik dapat disimpulkan bahwa yoghurt $\mathrm{P}_{1}$ paling disukai oleh panelis karena mendapatkan penilaian tertinggi terhadap aroma dan kesan, selain itu $\mathrm{P}_{1}$ juga mempunyai rasa asam/khas $(3,16)$ dan kekentalan sedang $(2,76)$.

Menurut Badan Standardisasi Nasional (SNI) 2981:2009, yoghurt merupakan fermentasi susu yang mempunyai bau normal/khas, rasa asam/khas, konsistensi homogen dan penampakan cairan kental sampai padat, dengan demikian dapat dikatakan bahwa yoghurt sinbiotik $\mathrm{P}_{1}$ sudah memenuhi kriteria SNI yoghurt karena mempunyai aroma yang cukup disukai, rasa asam/khas dan tekstur yang sedang atau agak kental. 


\section{KESIMPULAN}

Berdasarkan hasil penelitian dapat disimpulkan bahwa penambahan FTUD sebagai prebiotik dapat meningkatkan kualitas dan daya terima konsumen terhadap yoghurt sinbiotik. Yoghurt sinbiotik yang dihasilkan memiliki kualitas yang baik sesuai dengan yoghurt Standar Nasional Indonesia. Yoghurt sinbiotik dengan konsentrasi FTUD 3\% paling disukai oleh panelis dan sudah memenuhi kriteria SNI yoghurt dengan aroma yang cukup disukai, rasa asam/khas dan tekstur yang cukup kental dengan jumlah total BAL 2,4 x $10^{8} \mathrm{CFU} / \mathrm{ml}$, kadar asam laktat $1,3 \%$ dan $\mathrm{pH} 4,2$.

\section{DAFTAR PUSTAKA}

Adriani, L. 2006. Bakteri Probiotik sebagai Starter dan Implikasi Efeknya Terhadap Kualitas Yoghurt, Ekosistem Saluran Pencernaan dan Biokimia Darah Mencit. Disertasi. Program Pascasarjana. Universitas Padjajaran, Bandung.

Badan Standardisasi Nasional. 2009. SNI Yoghurt (SNI 2981:2009). Badan Standardisasi Nasional, Jakarta.

Fardiaz, S. 1993. Analisis Mikrobiologi Pangan. PT. Raja Grafindo Persada. Jakarta.

Fathir, F.N. 2008. Pembuatan Yoghurt Sinbiotik dari Susu Kambing Peranakan Etawa Menggunakan Kultur Campuran Bakteri Asam Laktat sebagai Pangan Fungsional Pencegah Diare. Makalah Seminar. Fakultas Teknologi Pertanian. Institut Pertanian Bogor, Bogor.

Hadiwiyoto, S. 1994. Teori dan Proseduer Pengujian Mutu Susu dan Hasil Olahannya. Penerbit Liberty, Yogyakarta.

Hansen \& Mocquot. 1970. Bacteria Genomes Lactobacillus acidophilus. European Bioinformatics Institute. Retrieved on 200708-22

Hendraningsih, L. 2006. Daya Hidup Bakteri Selulolitik Asal Probiotik Yoghurt Sapi pada Media Pembawa Pollard. GAMMA 2(1): 5562.

Holt, J. 2004. Determination of Bacteriology. Cambridge University Press, Cambridge.

Indratininingsih, Widodo, Salasia, S.I.O. dan E.Wahyuni. 2004. Produksi Yoghurt
Shiitake (Yoshitake) sebagai Pangan Kesehatan Berbasis Susu. Jurnal.Teknologi dan Industri Pangan, 95(1).

Kusumawati, I. dan Zaini, N.C. 2005. Pengaruh Senyawa Prebiotik Dari Bawang Merah (Allium cepa) Terhadap Pertumbuhan Bakteri Probiotik. Majalah Farmasi Airlangga 5(1): 20-24.

Lisal, J.S. 2005. Konsep Probiotik dan Prebiotik untuk Modulasi Mikrobiota Usus Besar. $J$. Med. Nus 26(4): 256-262.

Nurwantoro, Sutaryo, Hartanti, D. dan H. Sukoco. 2009. Viabilitas Bifidobacterium bifidum, Kadar Laktosa dan Rasa Es Krim Simbiotik pada Lama Penyimpanan Suhu Beku yang Berbeda. J.Indon.Trop.Anim.Agric. 34(1): 16-21.

Purwijantiningsih, E. 2007. Pengaruh Jenis Prebiotik terhadap Kualitas Yogurt Probiotik. Biota 12(3): 177-185.

Rachrnan, A. 1989. Pengantar Teknologi Fermentasi. Pusat Antar Universitas Pangan dan Gizi, Institut Pertanian Bogor, Bogor.

Rahayu, K. 1987. Mikrobiologi pangan. PAU Pangan dan Gizi, Yogyakarta.

Rosa, N. 2010. Pengaruh Penambahan Umbi Garut (Maranta arundinaceae L) dalam Bentuk Tepung dan Pati sebagai Prebiotik pada Yoghurt sebagai Produk Sinbiotik Terhadap Daya Hambat Bakteri Escherichia coli. Artikel Penelitian. Program Studi Ilmu Gizi Fakultas Kedokteran. Universitas Diponegoro, Semarang.

Rukmana, R. 2000. Dahlia : Prospek Agribisnis dan Teknik Budidaya. Kanisius. Yogyakarta.

Salle, A.J. 1974. Fundamental Principle of Bacteriology. McGraw Hill Publishing Company Limited. Inc. New Dhelhi.

Saputri, A.R. 2012. Gula dari Bunga Dahlia Karya Prof.

Djumali. http://kampus.okezone.com/read/2012/07/24 /372/667554/gula-dari-bunga-dahlia-karyaprof-djumali. 12 November 2012.

Schlegel, H.G. 1994. Mikrobiologi Umum. Gadjah Mada University Press, Yogyakarta.

Soekarto, S.T. 1985. Penilaian Organoleptik untuk Industri Pangan dan hasil Pertanian. Bhatara Karya Aksara, Jakarta. 
Sudharmadji, S. 1984. Prosedur Analisa untuk Bahan Makanan dan Pertanian. Edisi ketiga, Liberti. Yogyakarta.

Suganda. 2012. Bisnis Plan Susu Yoghurt. Tugas Terstruktur Agribisnis Persusuan. Program Pascasarjana. Magister Ilmu Peternakan. Universitas Jendral Soedirman. Purwokerto.

Surono, L.S. 2004. Probiotik Susu Fermentasi dan Kesehatan. PT Tri Cipta Karya, Jakarta.

Susanti, D. 2005. Pembuatan Es Puter Yogurt Kedelai dengan Penambahan Probiotik Lactobacillus achidophilus dan Bifldobacterium bifldum. Skripsi. Fakultas Teknologi Pertanian. Institut Pertanian Bogor, Bogor.

Tamime, A.Y. and Robinson, R.K. 1989. Yoghurt Science and Technologi, 2nd, Cambridge: Woodheed Publishing.

Tanjung, R.I.K. 2009. Viabilitas dan Aktivitas Inulinase Khamir Pichia alni DUCC-y-004 setelah diradiasi Ultraviolet dengan Variasi Lama Penyinaran dan Waktu Inkubasi. Skripsi. Jurusan Biologi, Fakultas Sains dan Matematika. Universitas Diponegoro, Semarang.

Wahyudi, M. 2006. Proses Pembuatan dan Analisis Mutu Yoghurt. Buletin Teknik Pertanian 11(1): 12-16.

Waspodo, I.S. 2002. Efek Probiotik, Prebiotik dan Symbiotik Bagi Kesehatan. Bulletin Food and Beverage Industry $4^{\text {th }}$. Jakarta.

Wijanarka, Ferniah, R.S. dan Salamah. 2004. Produksi Inulinase Pichia alni DUCC-W4 pada Tepung Umbi Dahlia (Dahlia variabilis Willd) dengan Variasi Konsentrasi
Ammonium Nitrat dan Waktu Inkubasi. BIOMA 10(2): 58-64.

Widodo, W. 2002. Bioteknologi Fermentasi Susu. Pusat Pengembangan Bioteknologi. Universitas Muhammadiyah Malang. Malang.

Widowati, S., Titi, C.S. dan A. Zaharani. 2005. Ekstraksi, Karakterisasi, dan Kajian Potensi Prebiotik Inulin dari Umbi Dahlia (Dahlia pinnata L.). Jurnal IPB, Bogor.

S. 2006. Dahlia Bunganya Indah, Umbinya Mengandung Inulin. Sinar Tani Edisi 19-25 April 2006.

Yuliana, R. 2009. Produksi Prebiotik FOS (Fruktooligosakarida) dari Inulin Umbi Dahlia oleh Aktivitas Inulinase Khamir Kluyveromyces marxianus DUCC-Y-003 dan Pengujiannya Terhadap Pertumbuhan Bakteri Lactobacillus acidophilus FNCC-0051. Skripsi. Jurusan Biologi, Fakultas Sains dan Matematika. Universitas Diponegoro, Semarang.

Yusmarini dan Efendi, R. 2004. Evaluasi Mutu Soyghurt yang dibuat dengan Penambahan Beberapa Jenis Gula. Jurnal Natur Indonesia 6(2): 104-110.

Zain, W.N.H. 2010. Karakteristik Mikrobiologis Granul Kultur Starter dengan Sinbiotik Terenkapsulasi untuk Menghasilkan Yoghurt dan Dadih Sinbiotik. Tesis. Sekolah Pascasarjana. Institut Pertanian Bogor, Bogor. 